\title{
Research on Innovation of Logistics Management Personnel Training in Local Application-oriented Universities Against the Background of Innovation and Entrepreneurship*
}

\author{
Shanfu $\mathrm{Yu}$ \\ Huanghe Science and Technology University \\ Zhengzhou, China
}

\begin{abstract}
Mass entrepreneurship and innovation" has become the main theme of contemporary society. It is a question for local application-oriented universities about how to follow the trend in the training of logistics management personnel. College students, as the fresh troops of innovation and entrepreneurship, have greater development potential. They can give full play to their knowledge advantages, stimulate social creativity and use innovation to guide entrepreneurship that can drive employment. In the background of innovation and entrepreneurship, for local application-oriented universities, how to meet the requirements of the times to develop more talents much needed by the society has become the key point of teaching reform of logistics management major in local universities.
\end{abstract}

Keywords-innovation and entrepreneurship; logistics management; local application-oriented university; talent training

\section{INTRODUCTION}

In 2016, the National Development and Reform Commission, Ministry of Education and Ministry of Human Resources and Social Security jointly issued the Notice on Formulating the Plan for Developing the Industry-Education Integrated Development Planned Project in the "13th FiveYear Plan" (F.G.S.H. [2016] No. 547) to launch the industryeducation integrated development planned project in vocational education. In the 13th Five-Year Plan Period, the state plans to invest RMB 5 billion to support about 100 higher vocational colleges in deepening integration of industries into education and the university-enterprise cooperation so as to speed up the construction of modern vocational educational system and comprehensively strengthen vocational education's ability to serve economic society development. For colleges and universities, innovation entrepreneurship education is to develop students' innovation consciousness and entrepreneurship and help them gain rich entrepreneurial

*Fund project: 1. 2017 Teaching Reform Project of Huanghe Science and Technology College: Project No.: JGYB2017015, Project name: Research on Innovation of Logistics Management Personnel Training of Model Application-oriented University in the Background of Innovation and Entrepreneurship

2. The ninth group of key disciplines of Henan Province (Y.J.G

(2018) No. 119), Regional Economics, Education Department of Henan Province. knowledge and strong entrepreneurial skills through professional teaching and experiential learning, so that they can find and seek entrepreneurial opportunities and have ambition and courage to bear risks and forge ahead.

\section{INNOVATION OF LOGISTICS MANAGEMENT TALENT TRAINING MODE IS OF GREAT SIGNIFICANCE FOR LOCAL APPLICATION-ORIENTED UNIVERSITIES}

At present, "Made in China" is striding forward to "China Creation", and building an innovative country is the only way to realize "China Creation". Building an innovative country needs innovative talents whose development requires popularity and improvement of entrepreneurship education. Providing innovation and entrepreneurship education for college students is of great practical significance for these students to improve their comprehensive quality and enhance their ability to get employment.

The cultivation of innovative and entrepreneurial talents of logistics management undergraduate students is the key to facilitate China to move towards modern logistics, and developing innovative and entrepreneurial logistics management talents is also the requirements of the economic society for development. The core of logistics management is the management, which is an industry very suitable for developing college students' ability of innovation and entrepreneurship. However, we should also calmly consider the difficult problems existing in the logistics management innovation and entrepreneurship practice in colleges and universities, such as the formation of team, management mode and fund, etc., and we should keep thinking and improving these problems. We believe that with the in-depth cooperation between industry, universities and research institutes, the innovation and entrepreneurship education for logistics management majors will surely reach a new level. The vision of mass entrepreneurship and innovation will be realized, and we believe that undergraduates in logistics management major can realize the "Chinese Dream" of innovation and entrepreneurship.

President Xi Jinping has repeatedly emphasized, "we should strengthen the construction of employment and 
entrepreneurship service system to support and help students take the a good first step toward the society." Premier Li Keqiang also stressed this point for many times, that "we should strengthen employment guidance and entrepreneurship education, effectively implement the employment promotion plan for college graduates and encourage them to find jobs at the grassroots level. We will implement a plan to guide college students in starting businesses and support them to start up businesses in emerging industries." In recent years, to encourage college students' innovation and entrepreneurship, the central and local governments provide a series of preferential policies for college students, such as providing entrepreneurial platform, entrepreneurship training, entrepreneurship services and entrepreneurial subsidy, etc. Among them, some projects such as startup capital, tax reduction and exemption, innovation and entrepreneurship consulting and training services are playing a positive role in promoting innovation and entrepreneurship of college students. It has the characteristics of the times and also has the practical significance to reform the existing logistics management talents training mode so as to facilitate the carrying out of innovation and entrepreneurship work.

\section{CURRENT SituATION OF CULTIVATION OF LOGISTICS MANAGEMENT PROFESSIONAL APPLIED TALENTS IN LOCAL UNIVERSITIES}

In China, many local undergraduate colleges and universities have been pursuing enrollment and teaching level, but failed to consider that they, as local undergraduate colleges and universities, should undertake the mission of serving regional social economic development, so they set no scientific and reasonable talent training target, resulting in a difference between talent training and local demands. In terms of talent training, local application-oriented universities should attach importance to local economic development planning and regional characteristics, focus on serving local economical and social development. Only by keeping local characteristics, can they achieve characteristic development and obtain strong vitality and development prospect to realize curve overtaking in the end. Logistics management major, characterized by strong applicability, is required to develop practical talents with strong operational ability and high professional quality. For a discipline closely combining theory and practice, practical teaching is especially important in talent training mode. Some application-oriented universities still adopts the original long-standing talent training mode, curriculum system and teaching method, characterized by dull and out-dated contents, which no longer adapt to the demand of the industry for talents in the new era.

\section{A. Old-fashioned and Backward Course Content}

For a long time, the teaching of logistics management has formed a whole set of traditional theories. Moreover, in order to emphasize the integrity and systematicness of knowledge, the major courses overlap more frequently without effective convergence, and the curriculum is huge and inefficient. As an emerging industry, the logistics management industry has more new theories and new technologies. And practice is always in front of theory. Only traditional knowledge of traditional books cannot meet the needs of training talents.

\section{B. Weak Practice Teaching Link}

In the training program for logistics management professionals, although we set up professional cognitive practice, curriculum experiments, experimental courses, graduation practice and graduation design (thesis), there is a gap between the actual effect and the expected effect. Experimental courses and curriculum experiments should be explained at the enterprise site to reduce students' difficulty in understanding. But restricted by many conditions, it can only be carried out in the classroom. Although the experiment teacher will prepare the experiment course carefully, most of them require students to do experiments step by step. A confirmatory experiment which is lack of enlightenment and integration is not conducive to the training of students' practical ability.

\section{Lack of High-quality "Dual-qualification” Teaching Staff}

With the expansion of college enrollment, the number of students is increasing with the teachers staff expanding. Influenced by recruitment policy and other factors, young teachers who take the post of teachers are the majority. Most young teachers graduate from famous universities and have solid theoretical foundations. But most graduates work as teachers with insufficient experience. It will take years of training to become a high-quality "dual-teacher" teacher with both theoretical foundation and practical guidance ability.

\section{Relatively Insufficient Practice Teaching Base}

University teachers often have heavy tasks in teaching and research, and no special person develops practical teaching bases. The development and maintenance of practical teaching base requires a lot of energy to maintain, which often leads to a small number of teaching bases. And the admission of students is limited and cannot satisfy all students' needs. Coupled with the pressure of employment, students cannot feel at ease and have a good internship. They are busy in looking for a job, working as an internship while looking for a job. Some practice teaching bases have signed a school enterprise cooperation agreement which often become a mere formality. Due to various reasons, it cannot be fully utilized. All kinds of reasons have made the practice teaching bases fail to play the expected role.

\section{Measures to Promote Training OF Logistics MANAGEMENT TALENTS IN LOCAL APPLIED UNIVERSITIES}

The training objectives of logistics management professionals in local universities should be based on the logistics industry. Guided by market demand and characterized by local regional economic development, it is integrated into the local economic development industry chain, keeping pace with the times and adapting to the new normal situation and new situation. However, the goal of training talents for logistics management in most local colleges and universities shows the problem of homogeneity, which is monotonous and has no characteristics, which affects the quality of talent training. 
A. The Curriculum System Should Emphasize the Training of Application Ability

The curriculum system of applied logistics management professionals must be reasonably set according to the demand characteristics of social market, which should embody the characteristics of practicability, maneuverability, adaptability and advancement. In terms of curriculum structure, we should highlight the comprehensive skills training of applied logistics management talents. We can adopt the "foundation + module" curriculum system. "Foundation" includes three parts: public basic courses, discipline basic courses and professional basic courses. The curriculum of "module" can be built on the basis of the professional training objectives, industry background, professional orientation, and social market demand characteristics of each school, so as to achieve the application of logistics management professionals tailored training. In addition, when setting up the curriculum system, we should not act blindly or speak for ourselves, nor can we simply copy the courses of other institutions. A professional curriculum construction committee should be established by local government agencies, logistics industry associations, professional teachers in universities and logistics executives, who can discuss the curriculum structure and teaching material construction of applied logistics management professionals. Finally, the integration of theoretical teaching and practical teaching should be realized in curriculum design, and the theoretical teaching and practical teaching should be combined into one in teaching content. In the way of teaching, we should break the line between theory and practice. Adopting the method of practicing while learning theory in the laboratory, we must combine theory with practice and grasp theoretical knowledge in practice.

\section{B. Strengthening the Teaching of Practical Training}

In recent years, various colleges and universities have accumulated a lot of experience in the teaching of practice. It can be said that strengthening practical teaching has become the consensus of applied universities. In the future, logistics management personnel must highlight their comprehensive quality. And the concrete embodiment is to enable students to master the practical skills of logistics management in teaching and improve students' practical ability in practical work so as to enhance students' job adaptability. Strengthening practice teaching can enable students to understand theoretical knowledge and grasp practical skills in practice, which can help solve the contradiction between logistics management professional learning and job disjoint. At the same time, offcampus practice teaching requires universities to set up offcampus practice bases. It is necessary to strengthen the combination of schools and enterprises and realize the sharing of resources, so that students' professional ability and professional quality can be cultivated and improved in a real working environment.

\section{To Further Promote the All-round School-enterprise Cooperation}

The link of professional practice teaching in the talent training plan includes a set of complete practice teaching system including professional cognition experiment, course experiment, graduation paper (deign) and graduation practice. To guarantee the realization of practice teaching objectives in high quality and promote the talent cultivation quality, firstly, the teachers shall complete the theory courses in school and concentrate the course experiments in enterprises and the practice teaching shall be accomplished under the joint guidance of teachers in school and enterprise manger through aiming at the professional course experiment. The experiment courses that can be accomplished in the training room in school can be accomplished in school by relying on the training software and hardware. Use summer vacation to closely combine the social practice with professional practice. Visit and investigate in the enterprises and conduct internship under the leading and guidance of professional teachers so as to further improve the practical ability. Use the short peak of large-scale talent demand of enterprise in Double Eleven to adjust teaching plans and send the students to grassroots posts for practice and training so as to promote their practical ability. Secondly, cooperated with enterprises to develop orderoriented talent training mode and develop the projects including partner and shop manager of convenience stores. And open the convenience stores in schools through establishment of various kinds of order-oriented classes which will be deemed as the training base for student internship and can promote the practical ability of students.

\section{Accelerating "Innovative Dual-qualification" Teacher Cultivation}

The construction of teaching staff is directly related to major construction. Aiming at the current situation with seriously insufficient innovative teaching staff of logistics management major, we must adopt measures and enhance the strength of teaching staff construction and make such staff the "innovative-type dual-teaching" teacher team which possesses reasonable structure and excellent quality and can also adapt to the development of logistics industry and possesses the practical experience. To enhance the cultivation of full-time core teachers, we need to select and send excellent teachers to domestic and foreign colleges with excellent logistics education quality for further study so as to improve the theoretical level. At the same time, encourage teachers to take a temporary post in ports, logistics parks, logistics enterprises and distribution centers to enrich their practical experience. In the meantime, employ part-time teachers. Based on the teaching demands, we can employ the senior management of domestic and foreign famous logistics enterprises or the firstline operation and management personnel to hold the post as part-time teachers so as to cultivate the operation and practice abilities of students through experiential teaching.

\section{E. Promoting the Talent Cultivation Quality by Creating Professional Logistics Brand}

The cultivation of applied talents is the inevitable choice of development orientation of local colleges. Insisting on the road of transformation development of applied technology colleges is the requirement of economic and social development on college functions. The education and teaching quality is the lifeline of colleges, especially the newly constructed applied colleges must make great efforts to construct the brand specialties so as to drive the improvement of overall specialty 
construction level and better serve the local economic and social development. Currently, the colleges that set up logistics management specialty become more and more and the education market for logistics management talents becomes increasingly competitive. Various colleges need to rely on the talent market to create characteristics and build their own brands which shall be deemed as the priority among priorities in the specialty construction.

\section{F. Taking the College Student Innovation and Entrepreneurship Program and the Student Entrepreneurial Practice Associations as the Breakthrough of Talent Cultivation}

Organize the logistics management students to actively participate in various kinds of school practice, entrepreneurship competitions and social practice activities. For example, organize students to participate in the career development planning, innovation and entrepreneurship competitions of school, select excellent innovation and entrepreneurship teams to participate in the provincial-level and national-level career planning competitions, innovation and entrepreneurship competitions, "challenge cup" Chinese college students career planning competitions and other competitions and take such competitions as carrier so as to actively create the campus innovation and entrepreneurship atmosphere, cultivate the innovation and entrepreneurship consciousness and spirit of students and promote the innovation and entrepreneurship abilities of students.

The cultivation of higher education for talent cultivation is a systematic engineering and the applied college education for logistics management is the exploratory and open work. In the practical works, there is just little experience to be referred to. We need to combine with social demands to continuously practice, explore and research. Only in this way can the work of talent cultivation be continuously improved so as to cultivate high-quality applied talents who can meet the social demands.

\section{CONCLUSION}

The cultivation of applied talents is an inevitable choice for the development of local undergraduate colleges. Adhering to the transformation development road of applied technology universities is the requirement of economic and social development for the functions of university, as well as the need for the settlement, differentiate development and dislocation competition of colleges. Professional construction is the foundation and support of college personnel training and the quality of education and teaching is the lifeline of colleges and universities. Especially for newly-built applied undergraduate colleges, we must do a good job in brand professional construction, so as to drive the improvement of the overall professional construction level and better serve the local economic and social development.

\section{REFERENCES}

[1] Li Fengmei. Logistics Management Professional Digital Resources Construction of the Teaching Reform and Innovation Research [J]. Logistics Engineering and Management, 2017, 39(03):181-182.

[2] Yuan Jing. To Explore the Methods of Teaching Standardization Reform and Practice of Logistics Management Major [J]. Logistics Scitech, 2017, 40(10):160-161.

[3] Zhang Rui. Research on Teaching Quality Standards and Corresponding Guarantee System of Application-oriented Logistics Management Undergraduate Major [D]. Yangtze University, 2017.

[4] Lai Xiahong. Research on Logistics Management Professional Innovative Talents Training Mode under Supply Side Reform [A]. Research on Teachers' Teaching Ability Development - Collection of Scientific Research Achievements (Book IX) [C], 2017:6.

[5] Fu Ronghua. Discussion on the curriculum reform of logistics management specialty in Higher Vocational Colleges under the background of innovation and Entrepreneurship Education [J]. Education Teaching Forum, 2018(13):259-260. 